\title{
Analysis of salivary transcripts and antigens of the sand fly Phlebotomus arabicus
}

\author{
Jitka Hostomská1, Vêra Volfová1, Jianbing $\mathrm{Mu}^{2}$, Mark Garfield ${ }^{3}$, \\ Iva Rohoušová ${ }^{1}$, Petr Volf1, Jesus G Valenzuela*2 and Ryan C Jochim*2
}

\author{
Address: ${ }^{1}$ Charles University in Prague, Faculty of Science, Department of Parasitology, Vinicna 7, 12844 Praha 2, Czech Republic, ${ }^{2}$ Vector \\ Molecular Biology Unit, Laboratory of Malaria and Vector Research, NIAID, NIH, Rockville, MD, 20852, USA and ${ }^{3}$ Research Technologies Branch, \\ NIAID, NIH, Rockville, MD, 20852, USA \\ Email: Jitka Hostomská - jitka.hostomska@centrum.cz; Vêra Volfová - veravolf@seznam.cz; Jianbing Mu - jmu@niaid.nih.gov; \\ Mark Garfield - mgarfield@niaid.nih.gov; Iva Rohoušová - rohousova@seznam.cz; Petr Volf - volf@cesnet.cz; \\ Jesus G Valenzuela* - jvalenzuela@niaid.nih.gov; Ryan C Jochim* - rjochim@niaid.nih.gov \\ * Corresponding authors
}

Published: 25 June 2009

BMC Genomics 2009, 10:282 doi:10.1186/147|-2/64-10-282
Received: 17 March 2009

Accepted: 25 June 2009

This article is available from: http://www.biomedcentral.com/I47I-2/64/I0/282

(C) 2009 Hostomská et al; licensee BioMed Central Ltd.

This is an Open Access article distributed under the terms of the Creative Commons Attribution License (http://creativecommons.org/licenses/by/2.0), which permits unrestricted use, distribution, and reproduction in any medium, provided the original work is properly cited.

\begin{abstract}
Background: Sand fly saliva plays an important role in blood feeding and Leishmania transmission as it was shown to increase parasite virulence. On the other hand, immunity to salivary components impedes the establishment of infection. Therefore, it is most desirable to gain a deeper insight into the composition of saliva in sand fly species which serve as vectors of various forms of leishmaniases. In the present work, we focused on Phlebotomus (Adlerius) arabicus, which was recently shown to transmit Leishmania tropica, the causative agent of cutaneous leishmaniasis in Israel.
\end{abstract}

Results: A cDNA library from salivary glands of $P$. arabicus females was constructed and transcripts were sequenced and analyzed. The most abundant protein families identified were SPI5-like proteins, ParSP25-like proteins, D7-related proteins, yellow-related proteins, PpSP32-like proteins, antigen 5-related proteins, and $34 \mathrm{kDa}$-like proteins. Sequences coding for apyrases, hyaluronidase and other putative secreted enzymes were also represented, including endonuclease, phospholipase, pyrophosphatase, amylase and trehalase. Mass spectrometry analysis confirmed the presence of 20 proteins predicted to be secreted in the salivary proteome. Humoral response of mice bitten by $P$. arabicus to salivary antigens was assessed and many salivary proteins were determined to be antigenic.

Conclusion: This transcriptomic analysis of $P$. arabicus salivary glands is the first description of salivary proteins of a sand fly in the subgenus Adlerius. Proteomic analysis of $P$. arabicus salivary glands produced the most comprehensive account in a single sand fly species to date. Detailed information and phylogenetic relationships of the salivary proteins are provided, expanding the knowledge base of molecules that are likely important factors of sand fly-host and sand flyLeishmania interactions. Enzymatic and immunological investigations further demonstrate the value of functional transcriptomics in advancing biological and epidemiological research that can impact leishmaniasis. 


\section{Background}

Phlebotomine sand flies are the arthropod vectors of Leishmania parasites, the causative agents of leishmaniasis. During the feeding process sand flies inject saliva into the site of the bite to facilitate successful acquisition of a blood meal [1]. An infected sand fly regurgitates infective metacyclic promastigote stage Leishmania while feeding; thus, the parasite is always introduced to the host as a mixture with sand fly saliva. Sand fly saliva facilitates the transmission of Leishmania parasites to mammalian hosts; at the same time, immune response to salivary components was shown to partially protect the host from Leishmania infection [2]. Therefore, salivary components essential for parasite transmission and/or eliciting protective immune response are sought-after. Salivary proteins from Phlebotomus papatasi, the vector of Leishmania major, and Lutzomyia longipalpis, the vector of L. infantum, have been extensively studied. In addition, cDNA libraries from several other sand fly species were characterized and include other sand flies that vector $L$. major ( $P$. duboscqi), $L$. infantum (P. ariasi and P. perniciosus) and L. donovani $(P$. argentipes).

Phlebotomus (Adlerius) arabicus is distributed in certain parts of East Africa and the Middle East. In Ethiopia, P. arabicus females infected with uncharacterized Leishmania sp. were reported [3], and in northern Israel $P$. arabicus is the proven vector of cutaneous leishmaniasis caused by $L$. tropica $[4,5]$. Cutaneous leishmaniasis caused by L. tropica is found in a vast discontinuous area reaching from the south-western Mediterranean to Turkey, north-western India and Sub-Saharan Africa [6]. Long supposed to circulate in anthroponotic foci exclusively, L. tropica was recently shown to occur as an anthropozoonosis as well $[4,5]$. Laboratory experiments demonstrated that $P$. arabicus is a permissive vector, meaning it is susceptible to development of more than one species of Leishmania, including L. major and L. infantum [7].

In the present study, salivary gland transcripts and proteins of $P$. (Adlerius) arabicus were studied by cDNA sequencing, electrophoretic and proteomic methods. This is the first study of the repertoire of salivary molecules of a vector of L. tropica and it is the first report of the composition of salivary proteins in the subgenus Adlerius.

\section{Results and Discussion}

\section{Sequencing of salivary gland cDNA library}

A cDNA library was constructed from salivary glands of Phlebotomus arabicus females dissected one day after emergence. From this cDNA library, 1152 random transcripts were selected and sequenced, resulting in 985 high quality sequences. Sequences were clustered together based on sequence homology and produced 107 clusters and 288 sequences were assessed as singletons (only one sequence). The term cluster may refer to either singletons or multiple homologous sequences. Similar to other sand flies studied so far, the most abundant transcripts were those coding for putative secretory proteins and resulted in 74 clusters with an average number of 7.65 sequences per cluster. Predicted proteins containing retention signals for endoplasmic reticulum and/or transmembrane domains were not treated as putatively secreted. An example of such proteins is the translocon-associated protein complex, $\delta$ subunit (PabSP91; GenBank accession number FJ427208), which has homologs previously designated as $16 \mathrm{kDa}$ or $16.1 \mathrm{kDa}$ salivary protein in P. ariasi or L. longipalpis, respectively.

Members of 21 different families were found among putative secretory proteins. BLAST comparison of translated nucleotide sequences with the NR protein database showed that overall, high similarity was observed namely with salivary proteins of $L$. infantum vectors $P$. (Larroussius) ariasi and $P$. (L.) perniciosus. The expected values of these matches were highly significant at values lower than $\mathrm{E}^{-60}$. To a lesser extent, similarity to sequences of salivary proteins of $P$. (Euphlebotomus) argentipes, the vector of $L$. donovani in India, was also observed. These findings are fully in concert with the close evolutionary relationship of Larroussius and Adlerius subgenera reported by Aransay et al. [8].

Some of the protein families contained multiple members. The observed variability among individual protein family members might be explained by intraspecific polymorphism, as the tested sample was heterogeneous (a pool of salivary glands from 30 female sand flies). Nevertheless, analysis of genetic variation of SP15 salivary protein in P. papatasi brought strong evidence that SP-15 is a multicopy gene [9]. While individual intraspecific variability of sand fly salivary proteins awaits broader analysis, we propose that the multiple homologous transcripts within protein families observed in this $P$. arabicus salivary gland cDNA library may reflect gene duplication events or allelic variation.

Full-length sequences were obtained for most clusters coding for putatively secreted proteins. Only sequences containing a signal peptide and a polyA tail in the coding cDNA were considered full-length. Table 1 lists clusters for which full length sequences were obtained, including the name of the sequence, the best match to NCBI NR database, the predicted molecular weight $\left(\mathrm{M}_{\mathrm{w}}\right)$ and isoelectric point (pI) of the mature protein, and the GenBank accession number of the nucleotide coding sequence. The table also includes information on the presence of individual proteins in $P$. arabicus salivary proteome, as confirmed by Edman degradation and/or mass spectrometry. A more detailed description of the putative secreted proteins fol- 
Table I: Most abundant salivary protein transcripts from Phlebotomus arabicus

\begin{tabular}{|c|c|c|c|c|c|c|c|c|c|}
\hline \multirow[t]{2}{*}{ Cluster } & \multirow[b]{2}{*}{ Sequence name } & \multirow[b]{2}{*}{ Protein detected } & \multirow[b]{2}{*}{ Seq per cluster } & \multicolumn{3}{|c|}{ Best match to NR protein database } & \multirow[t]{2}{*}{$\mathrm{pl}$} & \multirow[t]{2}{*}{$M_{w}$} & \multirow[t]{2}{*}{ GenBank accession \# } \\
\hline & & & & $\mathrm{ACCN} \#$ & Organism & E value & & & \\
\hline PabSP2 & $\begin{array}{l}\text { I4 kDa salivary } \\
\text { protein } \mathrm{A}\end{array}$ & Y & 70 & 61817267 & P. ariasi & $5 \mathrm{E}-062$ & 9.1 & 14.2 & F]538III \\
\hline PabSP20 & $\begin{array}{l}\text { D7-related salivary } \\
\text { protein A }\end{array}$ & Y & 50 & 74099915 & P. ariasi & IE- 108 & 9.22 & 26.9 & FJ538107 \\
\hline PabSPI5 & $\begin{array}{l}27 \mathrm{kDa} \text { salivary } \\
\text { protein similar to } \\
\text { ParSP25 }\end{array}$ & Y & 49 & 61744161 & P. ariasi & $9 \mathrm{E}-092$ & 5.04 & 26.7 & F]538100 \\
\hline PabSP26 & $\begin{array}{l}\text { yellow-related } \\
\text { salivary protein }\end{array}$ & Y & 29 & 61373243 & P. ariasi & 0.0 & 8.40 & 42.9 & F〕410293 \\
\hline PabSP4 & $\begin{array}{l}\text { antigen 5-related } \\
\text { protein }\end{array}$ & Y & 28 & 61373238 & P. ariasi & IE- 133 & 9.27 & 31.1 & FJ439532 \\
\hline PabSPI4 & $\begin{array}{l}25 \mathrm{kDa} \text { salivary } \\
\text { protein A similar to } \\
\text { ParSP25 }\end{array}$ & Y & 18 & 61744161 & P. ariasi & $3 \mathrm{E}-090$ & 5.04 & 24.8 & FJ538102 \\
\hline PabSP3I & $\begin{array}{l}25 \mathrm{kDa} \text { salivary } \\
\text { protein similar to } \\
\text { ParSPO2 }\end{array}$ & $Y$ & 14 & 61817261 & P. ariasi & 7E-066 & 10.27 & 25.0 & EZ000628 \\
\hline PabSP52 & $\begin{array}{l}\text { putative salivary } \\
\text { phospholipase A2 }\end{array}$ & & 14 & 76446615 & P. perniciosus & IE- $\mid 50$ & 8.76 & 29.8 & $\underline{E Z 000627}$ \\
\hline PabSP49 & $\begin{array}{l}\text { putative salivary } \\
\text { endonuclease }\end{array}$ & $Y$ & 14 & 61807170 & P. ariasi & 0.0 & 9.45 & 40.5 & Fృ439531 \\
\hline PabSP53 & $\begin{array}{l}46 \mathrm{kDa} \text { salivary } \\
\text { protein }\end{array}$ & & 12 & 76446617 & P. perniciosus & IE- $\mid 72$ & 5.97 & 46.4 & F]538106 \\
\hline PabSP34 & $\begin{array}{l}34 \mathrm{kDa} \text {-like salivary } \\
\text { protein B }\end{array}$ & $Y$ & 12 & 61807168 & P. ariasi & IE-139 & 8.89 & 34.1 & F]489242 \\
\hline PabSP45 & $\begin{array}{l}\text { I } 4 \text { kDa salivary } \\
\text { protein B }\end{array}$ & $Y$ & 12 & 61807162 & P. ariasi & $8 \mathrm{E}-060$ & 9.33 & 14.2 & F]538112 \\
\hline PabSP30 & $\begin{array}{l}26 \mathrm{kDa} \text { salivary } \\
\text { protein similar to } \\
\text { ParSPO2 }\end{array}$ & $Y$ & 12 & $6181726 \mid$ & P. ariasi & IE-068 & 10.32 & 26.3 & EZ000629 \\
\hline PabSP39 & salivary apyrase A & $Y$ & II & 61817259 & P. ariasi & IE-167 & 8.89 & 35.3 & EZ000633 \\
\hline PabSP56 & $\begin{array}{l}2.7 \mathrm{kDa} \text { salivary } \\
\text { peptide }\end{array}$ & & 9 & 61744159 & P. ariasi & 0.015 & $|2.3|$ & 2.7 & F]538099 \\
\hline PabSP32 & $\begin{array}{l}34 \mathrm{kDa} \text {-like salivary } \\
\text { protein } \mathrm{A}\end{array}$ & $Y$ & 8 & 61807168 & P. ariasi & IE- 160 & 8.89 & 34.0 & F] 489241 \\
\hline PabSP29 & $\begin{array}{l}28 \mathrm{kDa} \text { salivary } \\
\text { protein similar to } \\
\text { ParSPO2 }\end{array}$ & & 8 & $6181726 \mid$ & P. ariasi & $4 \mathrm{E}-069$ & 10.52 & 27.8 & EZ000630 \\
\hline PabSP54 & $\begin{array}{l}\text { D7-related salivary } \\
\text { protein C }\end{array}$ & $Y$ & 7 & 61744153 & P. ariasi & IE- 103 & 9.11 & 26.7 & F]538109 \\
\hline PabSP59 & $\begin{array}{l}\text { D7-related salivary } \\
\text { protein B }\end{array}$ & & 7 & 61807164 & P. ariasi & IE-I02 & 9.42 & 27.4 & F]538108 \\
\hline PabSPI 6 & $\begin{array}{l}25 \mathrm{kDa} \text { salivary } \\
\text { protein B similar to } \\
\text { ParSP25 }\end{array}$ & $Y$ & 6 & $61744|6|$ & P. ariasi & IE-089 & 5.03 & 24.8 & F]538103 \\
\hline PabSPI3 & $\begin{array}{l}25 \mathrm{kDa} \text { salivary } \\
\text { protein C similar to } \\
\text { ParSP25 }\end{array}$ & $Y$ & 5 & 61744161 & P. ariasi & $6 \mathrm{E}-091$ & 5.04 & 24.9 & FJ538104 \\
\hline PabSP72 & salivary hyaluronidase & & 4 & 4887110 & Lu. longipalpis & $2 \mathrm{E}-096$ & 9.07 & 53.0 & FJ439533 \\
\hline PabSP4I & salivary apyrase $C$ & $Y$ & 4 & 61817259 & P. ariasi & IE-168 & 8.89 & 35.3 & EZ000631 \\
\hline PabSP75 & $\begin{array}{l}10 \mathrm{kDa} \text { salivary } \\
\text { protein similar to } \\
\text { ParSPI3 }\end{array}$ & & 4 & 61744147 & P. ariasi & $2 \mathrm{E}-032$ & 4.56 & 10.3 & FJ474087 \\
\hline PabSP63 & $\begin{array}{l}16 \mathrm{kDa} \text { salivary } \\
\text { protein A }\end{array}$ & & 4 & 74486577 & P. argentipes & $4 \mathrm{E}-032$ & 5.36 & 15.9 & FJ474085 \\
\hline PabSP93 & $\begin{array}{l}\text { I4 kDa salivary } \\
\text { protein C }\end{array}$ & & 3 & 61807166 & P. ariasi & $4 \mathrm{E}-055$ & 9.22 & 14.1 & F]538113 \\
\hline PabSP64 & $\begin{array}{l}16 \text { kDa salivary } \\
\text { protein B }\end{array}$ & & 3 & 74486577 & P. argentipes & $6 \mathrm{E}-033$ & 5.18 & 16.0 & F] 474086 \\
\hline PabSP97 & $\begin{array}{l}10 \mathrm{kDa} \text { salivary } \\
\text { protein similar to } \\
\text { ParSP2 I }\end{array}$ & & 3 & 61744157 & P. ariasi & $5 \mathrm{E}-50$ & 5.11 & 10.3 & FJ474088 \\
\hline
\end{tabular}


Table I: Most abundant salivary protein transcripts from Phlebotomus arabicus (Continued)

\begin{tabular}{|c|c|c|c|c|c|c|c|c|c|}
\hline PabSPI2 & $\begin{array}{l}25 \mathrm{kDa} \text { salivary } \\
\text { protein D similar to } \\
\text { ParSP25 }\end{array}$ & $\bar{Y}$ & 3 & $61744|6|$ & P. ariasi & $9 \mathrm{E}-090$ & 5.04 & 24.8 & F]538105 \\
\hline PabSPII & $\begin{array}{l}27 \mathrm{kDa} \text { salivary } \\
\text { protein B similar to } \\
\text { ParSP25 }\end{array}$ & $Y$ & 3 & 61744161 & P. ariasi & $2 \mathrm{E}-090$ & 4.97 & 26.6 & F]538101 \\
\hline PabSP40 & salivary apyrase B & $Y$ & 3 & 61817259 & P. ariasi & IE- 168 & 8.77 & 35.3 & $E Z 000632$ \\
\hline PabSP84 & $\begin{array}{l}\text { D7-related salivary } \\
\text { protein D }\end{array}$ & & 3 & 74099915 & P. argentipes & IE-053 & 9.34 & 28.1 & F]538110 \\
\hline PabSPI07 & $\begin{array}{l}22 \mathrm{kDa} \text { salivary } \\
\text { protein }\end{array}$ & & 2 & 94468382 & Ae. aegypti & IE-27 & 4.37 & 22.2 & $\underline{E Z 000635}$ \\
\hline PabSPI 26 & $\begin{array}{l}17 \mathrm{kDa} \text { salivary } \\
\text { protein }\end{array}$ & & 2 & $1.09 \mathrm{E}+08$ & Ae. aegypti & $5 E-049$ & 5.34 & 17.2 & EZ000636 \\
\hline
\end{tabular}

Detection of a protein in the proteome that matches the predicted peptide sequence of the transcript is denoted under Protein detected by "Y"

lows, starting with proteins encoded by the most abundant transcripts:

\section{SPI5-like proteins}

Thus far, SP15-like proteins have only been reported in sand flies and their function remains unknown. It was suggested that SP15-like proteins were derived from an ancestral odorant-binding protein and were closely related to short D7 proteins [10]. Immunization of mice with $P$. papatasi SP15 conferred partial protection against L. major infection [11]. Transcripts coding for these proteins represented the most abundant family in P. arabicus salivary gland cDNA library and clustered into three separate groups (PabSP2, PabSP45 and PabSP93; GenBank accession numbers FJ538111, FJ538112 and FJ538113, respectively). The amino acid sequences of mature proteins coded by $P$. arabicus transcripts share $22.5 \%$ amino acid identity and $23.3 \%$ amino acid similarity. When SP15-like proteins from other sand flies were added to the analysis, only the six cysteines and three other amino acids were conserved in the amino acid sequence of mature proteins (Figure 1A), reflecting the previously reported divergence among SP15-like proteins in sand flies [10]. In L. longipalpis a single SP15-like protein was found, SL1. In P. arabicus and other Phlebotomus spp. studied so far multiple members of the SP15 family are present. A phylogenetic analysis revealed three separate groups of $P$. arabicus SP15-like proteins, showing close relationships to $P$. ariasi proteins ParSP03, ParSP06 and Par08, respectively (Figure 1B). The predicted pI of all three $P$. arabicus SP15-like variants is highly basic (average $\mathrm{pI}=9.22$ ), corresponding to the fact that most Phlebotomus $s p p$. sand fly salivary proteins have very high predicted $\mathrm{pI}$ values.

\section{$27 \mathrm{kDa}$ and $25 \mathrm{kDa}$ proteins}

Six clusters coding for proteins related to P. ariasi $27 \mathrm{kDa}$ salivary protein (ParSP25; GenBank accession number AAX55664) and $P$. perniciosus $29 \mathrm{kDa}$ salivary protein (PpeSP08, GenBank accession number ABA43056) were found in the P. arabicus salivary gland cDNA library. There are no other homologs of these proteins in accessible databases, no conserved domains were found in the translated sequences, and no function has been assigned to these proteins. However, in $P$. arabicus cDNA library they represent the second most abundant protein family. Transcripts coding for ParSP25-like proteins occurred in long (PabSP15 and PabSP11; GenBank accession numbers FJ538100 and FJ538101) and short forms (PabSP14, PabSP16, PabSP13 and PabSP12; GenBank accession numbers FJ538102, FJ538103, FJ538104 and FJ538105, respectively), with very little variability among individual clusters. The mature proteins coded by these transcripts have a predicted $\mathrm{M}_{\mathrm{w}}$ of $27 \mathrm{kDa}$ and $25 \mathrm{kDa}$, respectively, and are composed of $90.5 \%$ identical amino acids and $0.9 \%$ similar amino acids. The predicted $\mathrm{pI}$ of the proteins is acidic (average pI = 5.03), unlike most sand fly salivary proteins described thus far.

\section{D7-related proteins}

D7 proteins are well known from the saliva of mosquitoes, sand flies, black flies and biting midges [12-15]. While the structure of anopheline D7 proteins allows binding of biogenic amines and components of the contact activation system of coagulation $[16,17]$, related proteins in sand flies lack conserved residues responsible for stabilizing bound ligands [18]. Thus, they may not interfere with host hemostasis by a similar mechanism and their function remains unknown. Mosquito D7 proteins elicit IgE in individuals hypersensitive to mosquito bites [19] and antibodies against sand fly D7 proteins were found in dogs naturally exposed to L. longipalpis [20]. Thus, it is possible that sand fly D7 proteins are involved in human hypersensitivity to sand fly bites. Four clusters of sequences coding for D7-related proteins were found in the $P$. arabicus salivary gland cDNA library (PabSP20, PabSP59, PabSP54 and PabSP84; GenBank accession numbers FJ538107, FJ538108, FJ538109 and FI538110, respectively). Predicted mature proteins have $M_{w}$ of 26-28 $\mathrm{kDa}$ and an average basic PI of 9.24. Two of the seven clus- 
A

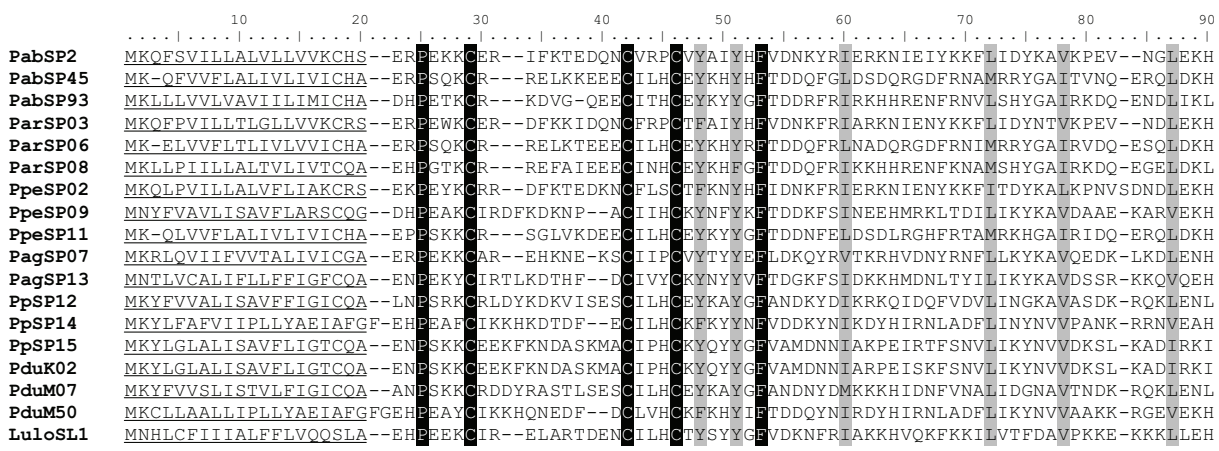

\begin{tabular}{ll|l|l} 
& \multicolumn{1}{c}{100} & 110 & 120
\end{tabular}$\ldots$

\section{B}

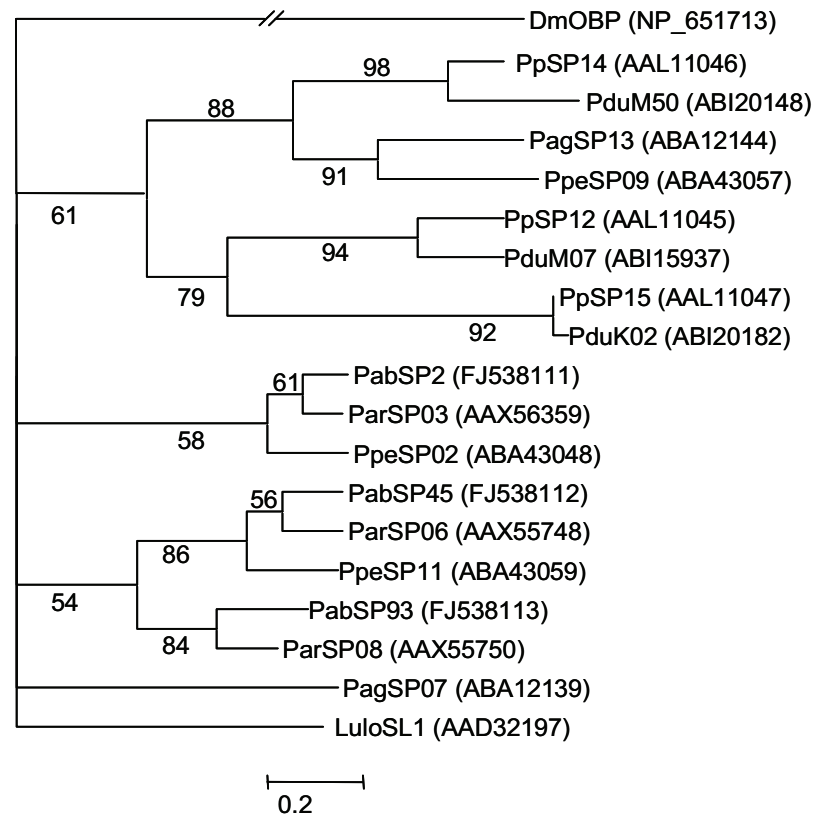

Figure I

Analysis of sand fly salivary proteins of the SP I 5 family. (A) Multiple sequence alignment of SPI5 and SPI5-like salivary proteins from Phlebotomus arabicus (Pab), P. ariasi (Par), P. argentipes (Pag), P. perniciosus (Ppe), P. papatasi (Pp), P. duboscqi (Pdu), and Lutzomyia longipalpis (Lulo). The predicted signal secretion peptide is underlined. Identical amino acid residues are highlighted black and similar residues are highlighted grey. (B) Phylogenetic analysis of amino acid sequences of SPI 5 and SPI5-like salivary proteins from sand flies and an oderant-binding protein of Drosophila melanogaster (DmOBP). Accession numbers are in parentheses and node values indicate branch support. 
ters have potential $\mathrm{N}$-glycosylation sites, as predicted by NetNGlyc server. The protein sequences of mature proteins were $20.3 \%$ identical and $15.5 \%$ similar (Figure 2A). The phylogenetic analysis showed four distinct clades among $P$. arabicus D7-related proteins, all of them bearing high similarity to $P$. ariasi and $P$. perniciosus proteins (Figure $2 \mathrm{~B})$.

\section{Yellow-related proteins}

Yellow-related proteins are common in insects; in bloodsucking Diptera, yellow-related proteins were described from mosquitoes and sand flies. In Ae. aegypti, a dopachrome-converting enzyme shares homology with Drosophila melanogaster yellow proteins [21] and, according to Li et al. [22], it might play a role in melanotic encapsulation of parasites in the hemocoel. In sand fly salivary gland samples, however, dopachrome-converting enzyme activity could not be detected (Hostomska, unpublished observations), while yellow protein of $P$. duboscqi was detected in midgut and salivary glands and shown to have lectin properties [23]. Sand fly yellow proteins were previously proposed as potential antigens recognized by sera of experimentally bitten mice and dogs, and naturally exposed humans [24-26]. In L. longipalpis this was also suggested by mass spectrometry [20]. In the $P$. arabicus salivary gland cDNA library a single homolog of yellowrelated proteins was found (PabSP26; GenBank accession number FJ410293). The predicted $\mathrm{M}_{\mathrm{w}}$ of the protein is $42.9 \mathrm{kDa}$ with a pI of 8.4. No N-glycosylation sites were predicted in the protein sequence by amino acid submission to the NetNGlyc server.

\section{PpSP32-like proteins}

PpSP32-like proteins, so named due to homology with proteins described from $P$. papatasi, have only been found in sand flies and their function is unknown. In P. perniciosus they possess a collagen-related internal sequence [10]. In P. arabicus, however, these proteins bear no significant similarity to collagen; this feature is shared with PpSP32-like proteins of $P$. papatasi, $P$. ariasi or P. argentipes. Similarly to other protein families analyzed, the phylogenetic position of $P$. arabicus PpSP32-like proteins is close to that of $P$. ariasi and $P$. perniciosus homologs (Figure 3A). Three different transcript clusters coding for PpSP32-like proteins were found in the P. arabicus salivary gland cDNA library (PabSP31, PabSP30 and PabSP29; GenBank accession numbers EZ000628, EZ000629 and EZ000630, respectively), the mature proteins being $88.1 \%$ identical (Figure 3B). The variable length of the central glycine-rich region of the protein sequence results in three different variants of mature proteins. The predicted $M_{w}$ of the three variants are 25, 26.3 and $27.8 \mathrm{kDa}$. In all three variants of these proteins, there are alternating regions of very acidic ( $\mathrm{pI} 4.0$ ) and very basic ( $\mathrm{pI}>11.5$ ) amino acids (Figure $3 \mathrm{C}$ ). As shown in figure $3 \mathrm{C}$, the basic regions include the central glycine-rich sequence and the C-terminal basic tail. No N-glycosylation sites were predicted for these proteins by the NetNGlyc server.

\section{Antigen 5-related proteins}

Antigen 5 (Ag5) protein is present in vespid venom [27] and related proteins were reported in the saliva of bloodsucking insects $[28,29]$. Similar to most other sand fly species studied so far, only one cluster coding for Ag5-related protein was found in the $P$. arabicus cDNA library (PabSP4; GenBank accession number Fu439532) $[10,28,30]$. Mature Ag5-related proteins of sand flies are $45.6 \%$ identical and $14.5 \%$ similar, overall (Figure $4 \mathrm{~A}$ ). The phylogenetic analysis of Ag5-related proteins from sand flies, other blood-feeding insects and selected hymenopteran species shows a strongly supported distinct clade of sand fly Ag5-related proteins (Figure 4B). Unlike previous reports [10], this sand fly clade does not contain any Culicoides sequences. Close relationship of $P$. arabicus Ag5-related protein to P. perniciosus and P. ariasi was observed, much in the same way as in other salivary protein families (Figure 4B). The predicted $M_{w}$ of the mature protein is $31.1 \mathrm{kDa}$ and the $\mathrm{pI}$ is very basic (9.27).

\section{Apyrase}

Apyrases are widespread in saliva of bloodsucking insects. The antihemostatic effects of saliva are, for a great part, due to apyrase anti-platelet activity [31]. Sand fly apyrases belong to the Cimex apyrase family [32]. Three very similar apyrase clusters coding for apyrases were found in $P$. arabicus cDNA library $(98.4 \%$ identity) (PabSP41, PabSP40 and PabSP39; GenBank accession numbers EZ000631, EZ000632 and EZ000633, respectively). The predicted average $\mathrm{pI}$ of $P$. arabicus apyrases is 8.85 and the predicted $\mathrm{M}_{\mathrm{w}}$ is $35.3 \mathrm{kDa}$.

\section{Endonuclease}

A cluster encoding a putative endonuclease was identified in the P. arabicus CDNA library (PabSP49; GenBank accession number FJ439531). Similar sequences were reported from $P$. ariasi, $P$. perniciosus, $P$. argentipes, and L. longipalpis salivary glands. Cluster PabSP49 encodes an endonuclease domain, which is typical for DNA/RNA non-specific endonucleases. Since all residues composing the active site, the substrate binding site and the $\mathrm{Mg}^{2+}$ binding site are conserved in this cluster; we suggest that PabSP49 might possess endonuclease activity. The predicted pI of the mature protein is 9.45 and the predicted $\mathrm{M}_{\mathrm{w}}$ of the mature protein is $40.5 \mathrm{kDa}$. Possible roles for a salivary endonuclease include reducing the viscosity of the blood pool during feeding and liberating nucleosides. Exogenous nucleosides, primarily adenosine, can exhibit regulatory effects on blood clotting, immune and inflammatory responses, and Leishmania pathogenesis [33]. 


\section{A}

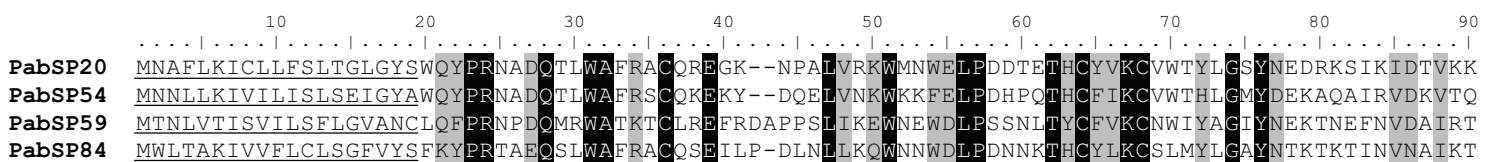
PabSP84 MWLTAKIVVFLCLSGFVYSFKYPRTAEQSLWAFRACQSEILP-DLNLLKOWNNWDLPDNNKTHCYLKCSLMYLGAYNTKTKT INVNAIKT
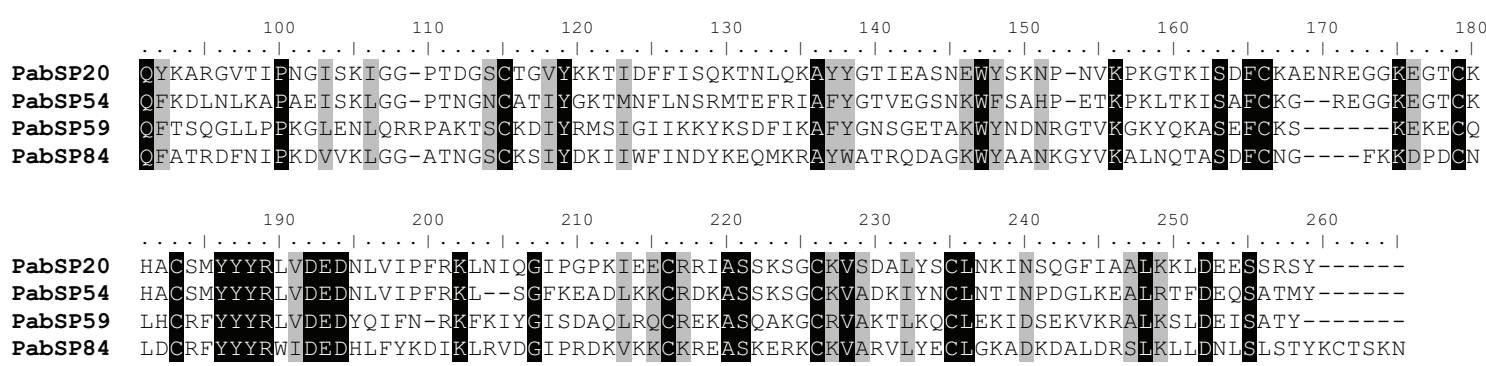

B

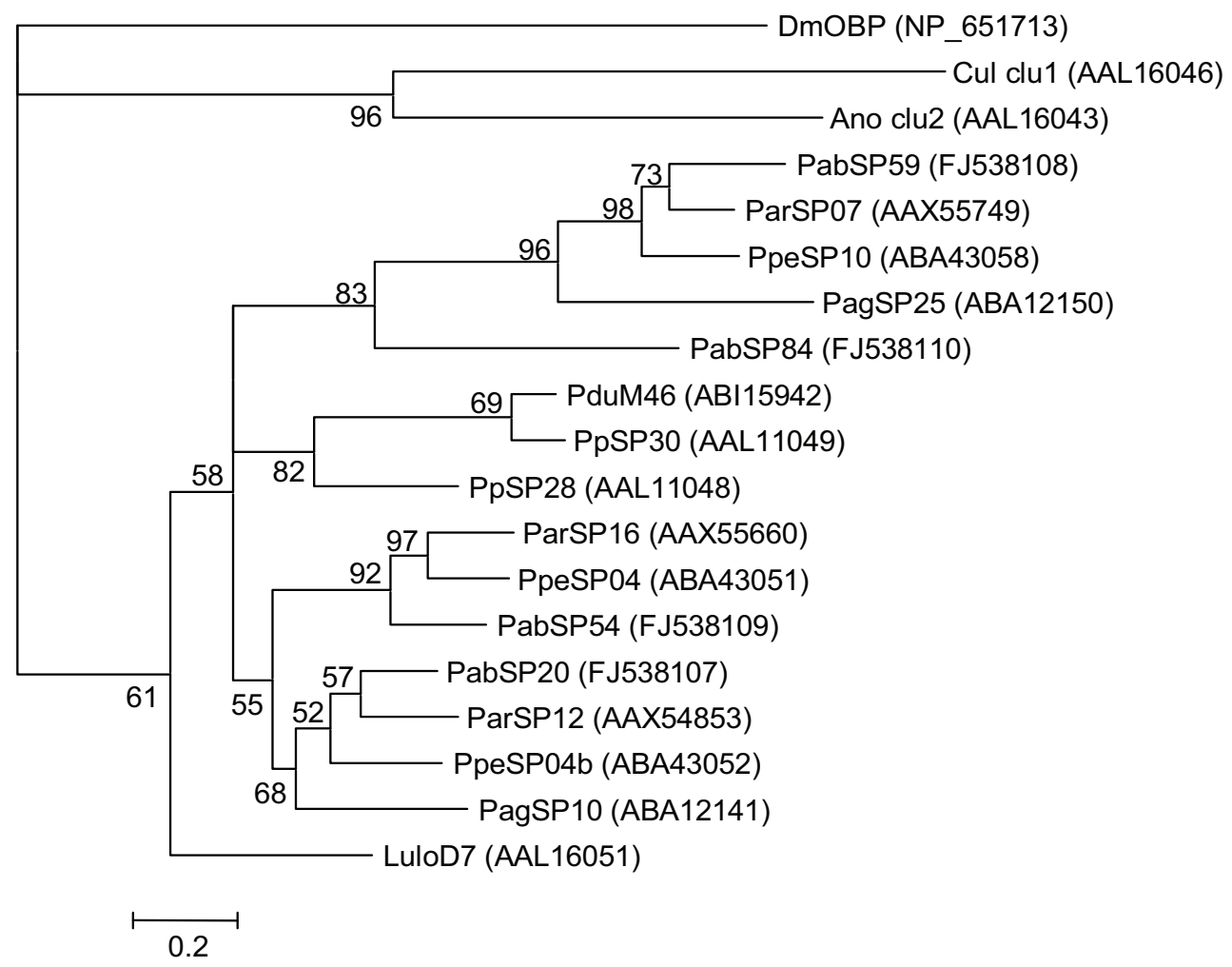

Figure 2

Analysis of the D7-related family of sand fly and mosquito salivary proteins. (A) Multiple sequence alignment of D7related salivary proteins from Phlebotomus arabicus (Pab). The predicted signal secretion peptide is underlined. Identical amino acid residues are highlighted black and similar residues are highlighted grey. (B) Phylogenetic analysis of amino acids of D7related proteins from P. ariasi (Par), P. perniciosus (Ppe), P. argentipes (Pag), P. papatasi (Pp), P. duboscqi (Pdu), and Lutzomyia longipalpis (Lulo), long form D7 proteins from mosquitoes Culex quinquefasciatus (Cul) and Anopheles stephensi (Ano), and odorantbinding protein from Drosophila melanogaster (DmOBP). Accession numbers are in parentheses and node values indicate branch support. 
A

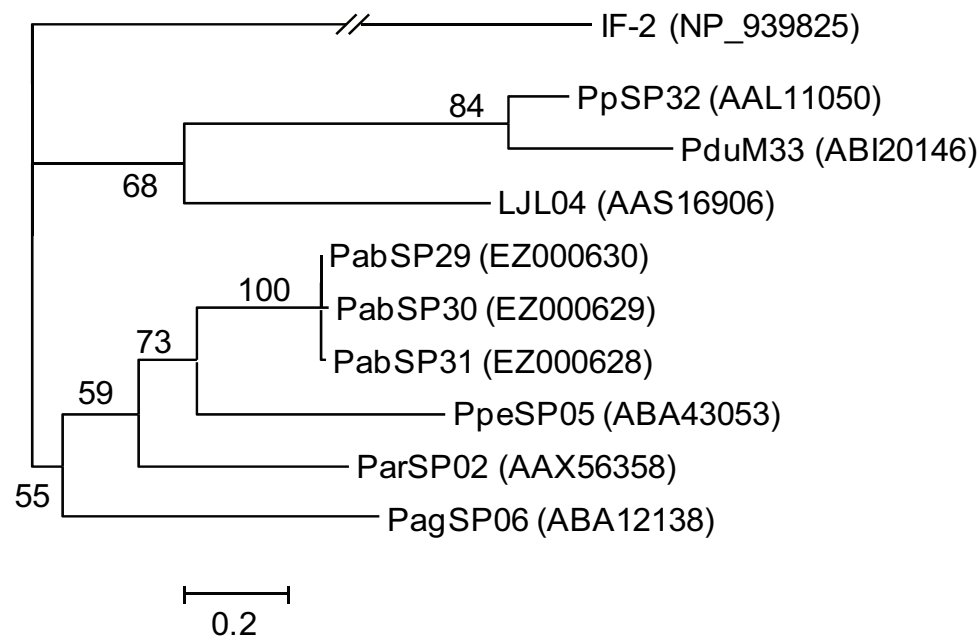

$\mathbf{B}$

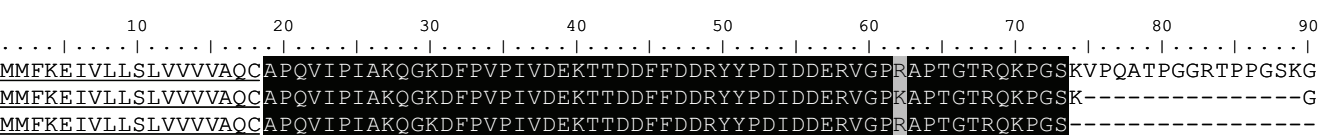

PabSP30

PabSP31

MMFKE IVI ISIVVVVAOCAPOVI PI AKOGKDFPVP IVDFKTTDDFFDDRYYPDI DDERVG

PabSP29

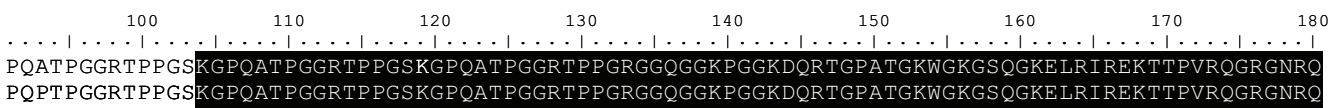

PabSP31

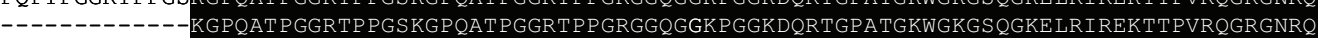

PabsP2
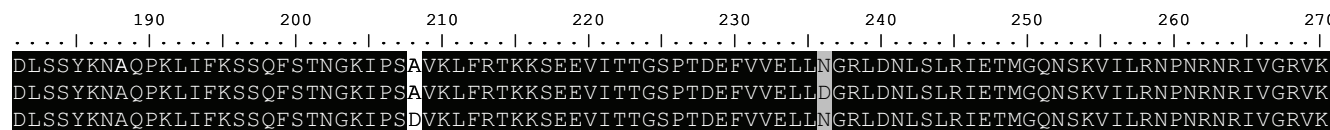

PabsP29

PabSP30

PabSP31

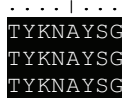

C

\begin{tabular}{|c|c|c|c|c|c|c|}
\hline PabSP29 & Sig & $\mathrm{pl}<4$ & 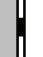 & $\mathrm{pl}>12$ & $\mathrm{pl}<4$ & $\mathrm{pl}>11$ \\
\hline PabSP30 & Sig & $\mathrm{pl}<4$ & 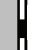 & $\mathrm{pl}>12$ & $\mathrm{pl}<4$ & $\mathrm{pl}>11$ \\
\hline PabSP31 & Sig & $\mathrm{pl}<4$ & 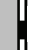 & $\mathrm{pl}>12$ & $\mathrm{pl}<4$ & $p l>11$ \\
\hline
\end{tabular}

\section{Figure 3}

Analysis of the PpSP32 family of sand fly salivary proteins. (A) Phylogenetic analysis of amino acids of PpSP32-like salivary proteins from Phlebotomus arabicus (Pab), P. ariasi (Par), P. perniciosus (Ppe), P. argentipes (Pag), P. papatasi (Pp), P. duboscqi (Pdu), and Lutzomyia longipalpis (LJL), and translation initiation factor from Corynebacterium diphteriae (IF-2). (B) Multiple sequence alignment of PpSP32-like salivary proteins from $P$. arabicus. The sequences of predicted signal peptides are underlined. Background shading represents identical and similar amino acids; black and grey, respectively. (C) Schematic alignment of PpSP32-like salivary proteins from P. arabicus. The predicted signal secretion peptide (Sig) and isoelectric point (pl) of specific blocks of amino acids are shown with acidic regions shaded grey. 

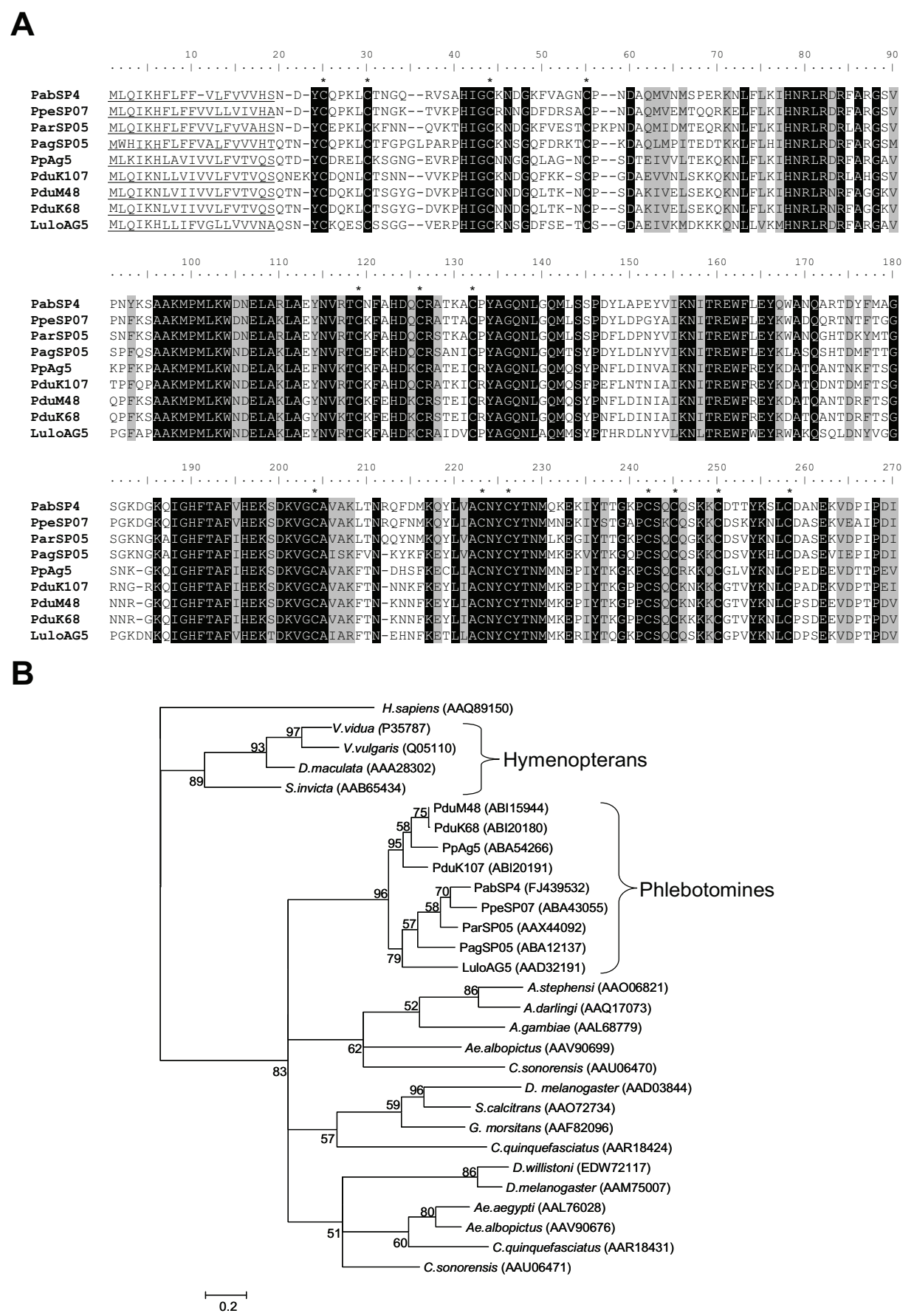

\section{Figure 4}

Analysis of Ag 5 and Ag 5-related proteins. (A) Multiple sequence alignment of Ag 5-related sand fly salivary proteins from Phlebotomus arabicus (Pab), P. ariasi (Par), P. perniciosus (Ppe), P. argentipes (Pag), P. papatasi (Pp), P. duboscqi (Pdu), and Lutzomyia longipalpis (Lulo). The sequences of predicted signal peptides are underlined. Background shading represents identical and similar amino acids; black and grey, respectively. Conserved cysteine residues are indicated by (*). (B) Phylogenetic analysis of $\mathrm{Ag} 5$ and $\mathrm{Ag} 5$-related protein amino acids from sand flies, Aedes aegypti, Ae. albopictus, Culex quinquefasciatus, Anopheles gambiae, An. darlingi, An. stephensi, Culicoides sonorensis, Stomoxys calcitrans, Glossina morsitans morsitans, Drosophila melanogaster, and D. willistoni, Vespula vidua, V. vulgaris, Dolichovespula maculata, and Solenopsis invicta, and a CRISP-family member from Homo sapiens. Accession numbers are in parentheses and node values indicate branch support. 


\section{Hyaluronidase}

Hyaluronidase activity has been detected in several species of bloodsucking insects including sand flies [34,35]. Accessible expressed sequence tag (EST) data from cDNA libraries of $P$. papatasi and $P$. duboscqi salivary glands do not contain hyaluronidase transcripts. Nonetheless, the enzyme activity was detected in salivary gland samples from these species [34], highlighting the potent enzymatic activity of a protein produced from a low abundance transcript. In salivary gland homogenate of $P$. arabicus, hyaluronidase activity was also observed. As revealed by zymography, the apparent molecular weight of the P. arabicus hyaluronidase holoenzyme is approximately 110 $\mathrm{kDa}$ (Figure 5), but no protein band correspond to the predicted molecular weight could be detected by silver or Coomassie staining in electrophoretically separated salivary proteins. These observations reflect the scarcity of both hyaluronidase transcript and hyaluronidase protein in sand fly salivary glands, and at the same time underline the remarkably high specific activity of the enzyme. In $P$. arabicus, the predicted pI for mature hyaluronidase is 9.07 and the $\mathrm{M}_{\mathrm{w}}$ is $53 \mathrm{kDa}$.

\section{Additional putative enzymes}

In the amino acid translation of sequence cluster 52 (PabSP52, GenBank accession number EZ000627), a phospholipase A2 (PLA2) domain is present, containing all conserved residues of both catalytic and metal-binding sites of PLA2. In hymenopteran venoms, PLA2 represents a major allergen. In the salivary glands of blood-feeding insects, sequences coding for PLA2-like proteins were reported only from sand flies of the subgenus Larroussius $[10,30]$. We tested salivary gland samples of $P$. arabicus specifically for PLA2 activity and did not detect any positive reaction. Cluster 52 contains an exceptionally long 5' untranslated region (5' UTR) compared to other clusters from this cDNA library coding for secreted proteins. The 5' UTR in this cluster is more than 500 nucleotides long. Thus, the regulation of expression of this transcript might be different from other transcripts reported herein.

Other sequences coding for other putative enzymes could not be obtained as full-length clones. These included a pyrophosphatase-like protein (PabSP288, GenBank accession number EZ000634), amylase (PabSP47, GenBank accession number EZ000626), an enzyme involved in digestion of dietary starch [36], and trehalase (PabSP315, GenBank accession number EZ000625). Previously, sequences coding for pyrophosphatase-like proteins were reported in $P$. argentipes and $P$. duboscqi sand flies $[10,37]$. These proteins, as well as their $P$. arabicus homolog reported herein, contain a conserved phosphodiesterase domain, typical for enzymes cleaving phosphodiester and phosphosulphate bonds in NAD, deoxynucleotides and nucleotide sugars [38]. Transcripts coding for $\alpha$-amylase

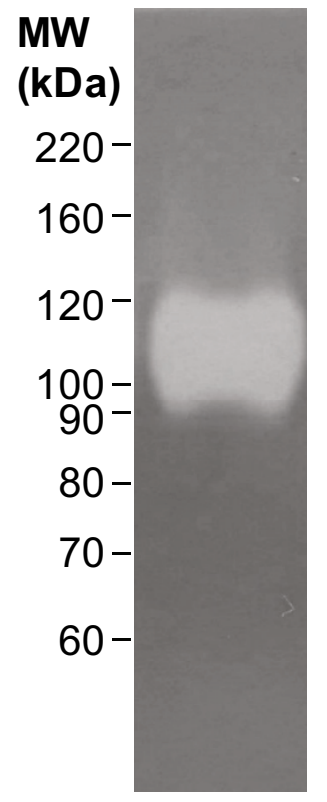

Figure 5

Zymographic assay for hyaluronidase activity detection in salivary glands of Phlebotomus arabicus. Gels with incorporated hyaluronan were used for electrophoretic separation of salivary gland samples.

were found in L. longipalpis salivary glands and midguts as well as $P$. papatasi midguts $[28,39,40]$. Amylase activity was shown in $L$. longipalpis and $P$. papatasi salivary gland samples $[28,36]$ and it is likely that the enzymatic activity is present also in $P$. arabicus salivary glands. The putative trehalase enzyme from $P$. arabicus salivary glands might either be an intrinsic component of insect metabolism, or might be related to sugar feeding and digestion. Trehalose is the main energy source in insect hemolymph in general. Trehalases are involved in its hydrolysis, yielding glucose molecules which are then readily available to various cells of the insect body [41]. So far, trehalase enzyme or sequence has not been reported from salivary glands of any blood-feeding insects, but sequences coding for sand fly trehalase have been found in midgut cDNA libraries of P. papatasi [40].

\section{Putative secreted proteins of unknown function}

There were a number of transcripts with no homology to known enzymes or structural proteins; however, eight of these transcripts encode potentially secreted proteins with high homology to other sand fly salivary molecules. $P$. arabicus salivary transcripts code for $34 \mathrm{kDa}$ proteins homologous to ParSP09. Polymorphisms resulting in different translations of the transcripts were observed (PabSP32 and PabSP34; GenBank accession numbers FJ489241 and FJ489242, respectively). These proteins are 
seemingly sand fly-specific; apart from 5 sand fly species (P. ariasi, P. perniciosus, P. argentipes, P. duboscqi and L. longipalpis); no other related proteins from any organism were reported. Another family of putative sand fly-specific proteins contain homologs of $P$. arabicus $46 \mathrm{kDa}$ salivary protein (PabSP53; GenBank accession number FI538106). Transcripts coding for such proteins were reported from $P$. perniciosus, $P$. ariasi, $P$. duboscqi and L. longipalpis. Homologs of P. arabicus 2.7 kDa peptide (PabSP56; GenBank accession number FJ538099) were only found in $P$. ariasi and $P$. perniciosus $[10,30]$. Our finding contradicts the suggestion that $2.7 \mathrm{kDa}$ peptides are specific for the subgenus Larroussius [10]. Likewise, two unrelated $10 \mathrm{kDa}$ proteins (PabSP75 and PabSP97; GenBank accession numbers FJ474087 and FJ474088, respectively) were found in $P$. arabicus; homologous molecules were identified in $P$. ariasi [30]. Additionally, two transcripts putatively encoding $16 \mathrm{kDa}$ salivary proteins (two polymorphic variants PabSP63 and PabSP64; GenBank accession numbers FJ474085 and FJ474086, respectively) are homologous to molecules identified in $P$. argentipes [10].

Two sequence clusters coding for putatively secreted proteins in the $P$. arabicus cDNA library show no similarity with known sand fly sequences. Cluster 107 (PabSP107; GenBank accession number EZ000635) is homologous to Ae. aegypti putative salivary secreted mucin 3, as well as the IgE binding protein icarapin from honeybee venom [42]. The predicted molecular weight of the mature protein is $22.2 \mathrm{kDa}$ and the putative protein would have an acidic pI of 4.4. There are 2 potential $\mathrm{N}$-glycosylation sites and 9 potential O-glycosylation sites in the amino acid sequence of cluster 107, as predicted by submission to the NetNGlyc and NetOGlyc servers. Similarly, putative extracellular proteins of Anopheles gambiae (XP_001230739) and Aedes aegypti (XP_001650286) were also predicted to contain multiple O-glycosylation sites. These proteins might be involved in hypersensitivity to bites of bloodfeeding insects. The second cluster 126 (PabSP126; GenBank accession number EZ000636), encodes a homolog of conserved hypothetical proteins of culicine as well as anopheline mosquitoes. The predicted molecular weight of the mature protein from $P$. arabicus is $17.2 \mathrm{kDa}$ and the predicted $\mathrm{pI}$ is 5.34 . No $\mathrm{N}$ - or O-glycosylation sites were predicted in cluster 126 protein and nothing is known about these hypothetical proteins.

\section{Proteome analysis of $\mathbf{P}$. arabicus salivary glands}

For the proteome analysis, $P$. arabicus salivary gland samples separated by SDS-PAGE were subjected to Edman degradation and mass spectrometry. Edman degradation resulted in the identification of 7 different N-terminal sequences. These were representative of two $14 \mathrm{kDa}$ proteins (PabSP2 and PabSP45; GenBank accession numbers FJ538111 and FJ538112, respectively), yellow-related protein (PabSP26; FJ410293), and endonuclease (PabSP49; FJ439531). An N-terminal sequence common to all six variants of salivary proteins similar to ParSP25 was also detected by Edman degradation (PabSP11-16; GenBank accession numbers FJ538100-FJ538105), as well as N-terminal sequences common to apyrases (PabSP39-41; EZ000631-EZ000633) and to D7-related proteins A and C (PabSP20 and PabSP54; FI538107 and FJ538109, respectively). From the data obtained by Edman degradation analysis it could not be concluded which variants of polymorphic salivary proteins were present in the proteome.

Mass spectrometry was used for a more detailed analysis of $P$. arabicus salivary proteome. By this method, 19 putative secreted proteins were identified in the proteome (Figure 6). These proteins include amylase (PabSP47, GenBank accession number ), yellow-related protein (PabSP26; GenBank accession number ), two 34 kDa salivary proteins (PabSP32 and PabSP34; GenBank accession number and, respectively), all three apyrase-like proteins (PabSP39-41; GenBank accession number , , ), two PpSP32-like proteins (PabSP31 and PabSP30; GenBank accession number and, respectively), antigen 5-related protein (PabSP4; GenBank accession number ), four 25 kDa salivary proteins similar to ParSP25 (PabSP14, PabSP16, PabSP13 and PabSP12; GenBank accession number, , and, respectively), three D7-related proteins (PabSP20, PabSP59 and PabSP54; GenBank accession number, and, respectively), and two PpSP15-like proteins (PabSP2 and PabSP45; GenBank accession number and, respectively). In addition, one high-molecular weight protein $(>70 \mathrm{kDa})$ analyzed by mass spectrometry revealed no similarity to predicted $P$. arabicus secreted salivary proteins. We assume this protein represents a component of salivary gland wall rather than a secreted protein present in the saliva. Accordingly, in P. duboscqi female salivary glands, we previously detected multiple protein bands running at molecular weight protein $>70$ $\mathrm{kDa}$ which were specifically present in the wall of salivary glands [43].

Additionally, glycoprotein-specific staining of electrophoretically separated proteins was performed. ProQ Emerald staining detected six glycoprotein bands in $P$. arabicus salivary gland samples (Figure 7). Three bands (B, C and D) correlate with proteins identified by mass spectrometry: amylase (PabSP47), yellow-related protein (PabSP26), and $34 \mathrm{kDa}$ proteins (PabSP32 and PabSP34). Band A is predicted to migrate at about $97 \mathrm{kDa}$ and may represent hyaluronidase; however, this band may be produced by the oligomerization of other salivary proteins or components of the gland structure. Bands $\mathrm{E}$ and $\mathrm{F}$ do not distinctly correlate with molecules identified by mass spectrometry and are therefore unknown. 


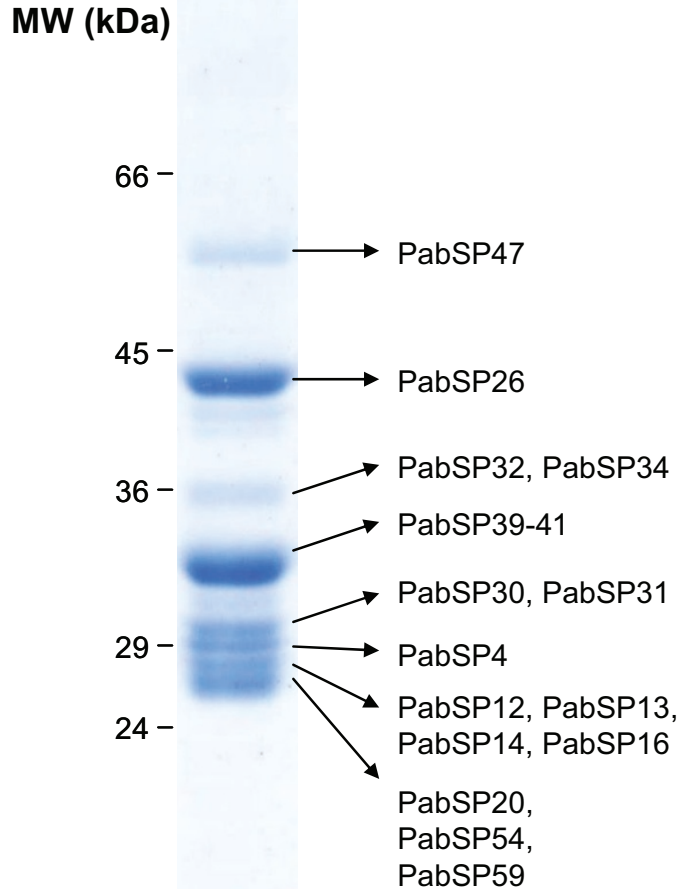

$20-$

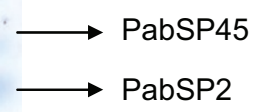

\section{Figure 6}

Mass-spectrometric analysis of salivary gland proteins from Phlebotomus arabicus. Salivary gland samples were electrophoretically separated and individual bands cut from the Coomassie-stained gel were analyzed by mass spectrometry. GenBank accession number of the corresponding protein coding sequence is listed for each protein identified.

\section{Humoral response to $P$. arabicus saliva}

Some of the proteins homologous to $P$. arabicus salivary proteins are known as antigens or allergens in other insect species. $P$. arabicus salivary proteins elicit a strong antibody response in mice exposed to $P$. arabicus feeding. In Western blots, the most prominent antigenic bands recognized by sera of two bitten mice (Figure 8, lanes 2 and 3) had apparent molecular weights of 56-58.5 kDa, $45 \mathrm{kDa}$, $43 \mathrm{kDa}$ (a double band), $42 \mathrm{kDa}, 34.5-36.5 \mathrm{kDa}$ and 30 $\mathrm{kDa}$. Slightly weaker reactions were observed with bands running at $31 \mathrm{kDa}$ and $30.5 \mathrm{kDa}$. In addition, sera from some animals recognized two very faint bands, running at $21 \mathrm{kDa}$ and $16 \mathrm{kDa}$ (Figure 8).

\section{Conclusion}

In this study we generated a transcriptome of female sand fly Phlebotomus arabicus salivary glands using a PCR-based cDNA library. This is the first reported salivary gland transcriptome of a sand fly from the subgenus Adlerius. The most abundant transcripts were represented in the 985 high quality sequences. Many of the transcripts encoded full- or partial-length proteins; most of which are homologous to other sand fly species saliva molecules. Phylogenetic analysis consistently shows a strong relationship between $P$. arabicus with sand flies from the Larroussius subgenus; specifically, $P$. ariasi and $P$. perniciousus. The phylogenetic analyses of sand fly salivary proteins reaffirm the taxonomy of phlebotomines [7].

Some of the most abundant molecules identified in the transcriptome that have a predicted signal secretion peptide include a $14 \mathrm{kDa}$ protein (PabSP2), a D7-related protein (PabSP20), a yellow-related protein (PabSP26), an Antigen 5-related protein (PabSP4) and $25 \mathrm{kDa}$ and 27 kDa proteins similar to $P$. ariasi ParSP25 (PabSP14 and PabSP15, respectively). A number of paralogous transcripts were identified, such as those in the SP15 and D7 families. The presence of duplicate gene copies has been observed in other blood feeding arthropods $[10,44]$ and can serve several potential functions including increased transcript abundance and rapid evolution of blood feeding strategies while retaining intrinsic proteins. Proteomic analysis by $\mathrm{N}$-terminal sequencing or tryptic digestion followed by mass spectrometry identified 20 proteins in the salivary gland homogenate of $P$. arabicus that were characterized in the transcriptome. In addition, one protein was identified by mass spectrometry that did not match any of the characterized transcripts. This is the most comprehensive description of sand fly salivary proteome to date and also demonstrates that the transcriptome represents $>95 \%$ of the most abundant proteins present in the salivary gland.

In the analysis of the $P$. arabicus salivary gland transcriptome four sequences were identified as encoding a putative hyaluronidase. Hyaluronidase is an enzyme that has been identified in a number of phlebotomine salivary glands including Lutzomyia longipalpis, P. Phlebotomus papatasi, P. Phlebotomus duboscqi, P. Paraphlebotomus sergenti and $P$. Adlerius halepensis [34]. The zymographic analysis of salivary gland extract confirms the presence of an active hyaluronidase enzyme and demonstrates the effectiveness of a transcriptomic approach to identifying disease vector salivary components.

Having described the repertoire of saliva molecules opens more doors in the research of vector-host and vector-parasite interactions, pharmacology and insect biochemistry. The antigenicity of sand fly saliva is one important aspect 


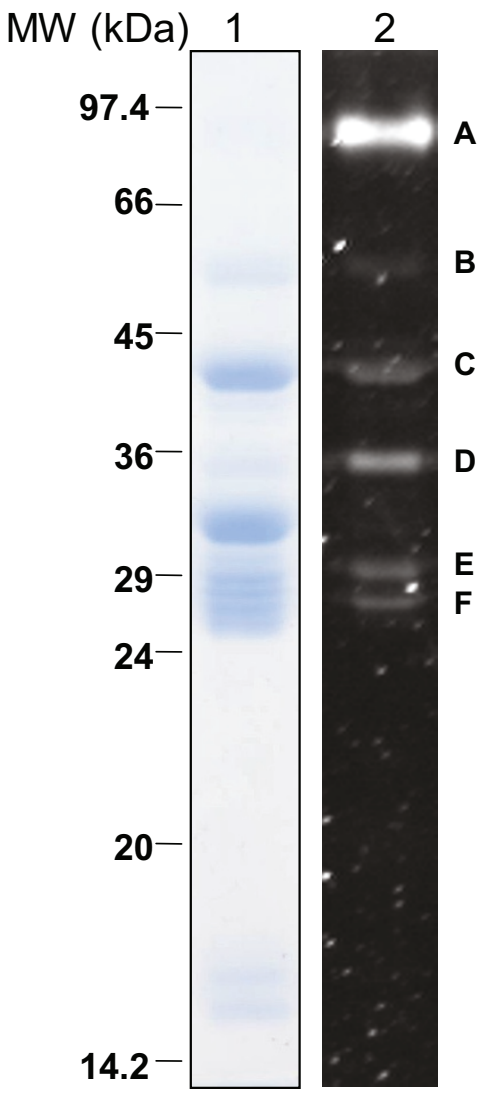

Figure 7

Glycoprotein-specific staining of Phlebotomus aribicus salivary glands. Salivary gland homogenate was electrophoretically separated in two wells of a polyacrylamide gel. The gel was cut in half with one portion stained with Coomassie (Lane I) and the other portion stained with ProQ Emerald 300 Glycoprotein Stain (Lane 2). Six bands were visualized by glycoprotein staining (A-F).

of the vector-host interaction. Evaluating the humoral response of mice bitten by $P$. arabicus demonstrates the abundance and diversity of antigenic molecules in the saliva. Future work may focus on the use of functional transcriptomics (expression of recombinant protein and biological and biochemical assays) to use these P. arabicus salivary proteins to evaluate the role of these molecules in the epidemiology of leishmaniasis.

\section{Methods}

\section{Sand flies and salivary gland dissection}

The colony of $P$. arabicus (Israel) was reared in the insectary of Charles University in Prague in standard conditions as described by Benkova and Volf [45]. For mRNA extraction salivary glands of 1-day-old females were dissected in saline and stored in RNA later (Ambion). For proteome analysis and Western blot analysis, salivary glands from 5- to 7-day-old $P$. arabicus females were dis-

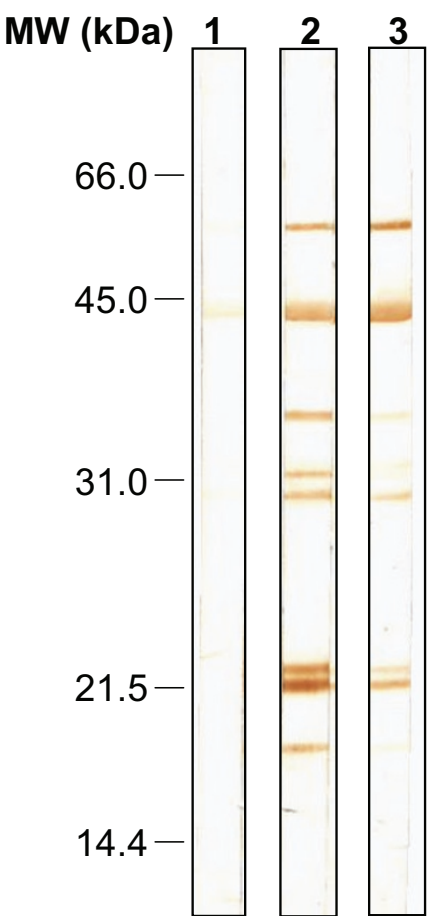

Figure 8

Humoral response to salivary gland antigens of Phlebotomus arabicus. SDS-PAGE and immunoblotting of $P$. arabicus salivary gland proteins with sera of BALB/c mice: (I) non-immune serum; (2), (3) sera from mice repeatedly exposed to bites of $P$. arabicus females.

sected and stored in Tris buffer (20 mM Tris, $150 \mathrm{mM}$ $\mathrm{NaCl}, \mathrm{pH} 7.5$ ).

\section{Construction of salivary gland cDNA library}

Salivary gland mRNA was isolated from 30 pairs of glands using Micro-FastTrack mRNA isolation kit (Invitrogen). PCR-based cDNA library was made following the manufacturer's instructions for SMART ${ }^{\mathrm{TM}}$ CDNA library Construction Kit (BD Clontech) with some modifications described by Chmelar et al. [46]. The cDNA library was fractionated into three sets of cDNAs containing large, medium and small fragments. Gigapack ${ }^{\circledR}$ III Gold Packaging Extract (Stratagene) was used for packaging the phage particles. The libraries were plated by infecting log-phase XL-1 blue Escherichia coli (Clontech). Several plaques from each plate were selected and a PCR with vector primers flanking the inserted cDNA was performed. The presence of recombinants was checked by visualisation the PCR products on $1.1 \%$ agarose gel with ethidium bromide.

\section{Sequencing of Selected cDNA Clones}

Plaques were randomly selected from the plated libraries and transferred to 96-well polypropylene plate containing $75 \mu \mathrm{l}$ of water per well. The PCR reaction amplifying ran- 
domly selected cDNAs was performed using FastStart PCR Master mix (Roche), $3 \mu \mathrm{l}$ of the phage sample as a template and primers described elsewhere [30]. Amplification conditions were as follows: 1 hold of $75^{\circ} \mathrm{C}$ for $3 \mathrm{~min}, 1$ hold of $94^{\circ} \mathrm{C}$ for $2 \mathrm{~min}$ and 34 cycles of $94^{\circ} \mathrm{C}$ for $1 \mathrm{~min}$, $49^{\circ} \mathrm{C}$ for $1 \mathrm{~min}$ and $72^{\circ} \mathrm{C}$ for $2 \mathrm{~min}$. Final elongation step lasted for $10 \mathrm{~min}$ at $72^{\circ} \mathrm{C}$. Reaction products were cleaned using ExcelaPure 96-Well UF PCR Purification Plates (EdgeBio) and used as templates for cycle-sequencing reaction using BigDye Terminator v3.1 cycle sequencing kit (Applied Biosystems) and a forward primer described elsewhere [30]. Cycle-sequencing reaction products were cleaned using sephadex and MultiScreen HV Plates (Millipore), dried and stored at $-20^{\circ} \mathrm{C}$. Sequencing was performed on an ABI 3730Xl DNA sequencer (Applied Biosystems).

\section{Bioinformatics}

Detailed description of the bioinformatic treatment of the data can be found elsewhere $[29,46]$. Briefly, EST trace files were analyzed using a customized program based on the Phred algorithm $[47,48]$. Sequences with Phred quality scores lower than 20 were removed, as well as primer and vector sequences. Resulting sequences were grouped into clusters using a customized program based on identity (95\% identity, 64 word size) and aligned into contiguous sequences (contigs) using the CAP3 sequence assembly program [49]. BLASTX, BLASTN or RPS BLAST programs [50] were used to compare contigs and singletons (contigs with a single sequence) to the non-redundant (NR) protein database of the NCBI, the gene ontology (GO) fasta subset [51], to the conserved domains database (CDD) of NCBI [52] which contains KOG ()[53], Pfam [54] and Smart databases[55], and to mitochondrial and rRNA nucleotide sequences available from NCBI. The three frame translations of each dataset were submitted to the SignalP server [56] to detect signal peptides. The grouped and assembled sequences, BLAST results and SignalP results were combined in an Excel spreadsheet and manually verified and annotated. $\mathrm{N}$ - and O-glycosylation site prediction was performed for selected sequences using NetNGlyc 1.0 and NetOGlyc 3.1 software (www.cbs.dtu.dk/services/NetNGlyc, www.cbs.dtu.dk/ services/NetOGlyc) [57].

\section{Phylogenetic analysis}

Protein sequences of the members of identified protein families were compared with related sequences of other sand fly species obtained from GenBank. Sequences were aligned using ClustalW version 1.4 [58] running under BioEdit sequence-editing software, version 7 , and manually refined in BioEdit. For each alignment, best substitution matrix was determined by ProtTest software, version 1.4 [59]. This matrix was then used by TREE-PUZZLE 5.2 [60] to reconstruct phylogenetic trees from the protein alignments by maximum likelihood. TREE-PUZZLE implements quartet puzzling $(\mathrm{QP})$ tree search; at the same time, the algorithm estimates support values for each internal branch. The number of puzzling steps was 1000 in each phylogenetic analysis. Resulting trees were viewed in MEGA 4 [61].

\section{Proteome analysis}

Salivary glands from 5-day-old $P$. arabicus females were homogenized by 5 freeze-thaw cycles. Samples were reduced using sample buffer with 2-mercaptoethanol, and electrophoretically separated in $12 \%$ polyacrylamide SDS gel. Gels were stained for total proteins with Coomassie G-250 (SimplyBlue SafeStain, Invitrogen) or for glycoproteins with Pro-Q Emerald 300 glycoprotein stain (Invitrogen). Mass spectrometric analysis was performed with individual bands cut from the Coomassie-stained gel. The individual bands were placed in microtubes and covered with $100 \mu \mathrm{l} 50 \mathrm{mM}$ ammonium bicarbonate (ABC) buffer in $50 \%$ acetonitrile $(\mathrm{ACN})$ with $50 \mathrm{mM}$ dithiothreitol (DTT). The samples were subjected to sonication in an ultrasonic bath for 5 minutes. After 15 minutes the supernatant was discarded and the gel was covered with $100 \mu \mathrm{l}$ of $50 \mathrm{mM} \mathrm{ABC} / 50 \% \mathrm{ACN}$ with $50 \mathrm{mM}$ iodoacetamide and sonicated for 5 minutes. After 25 minutes, the supernatant was discarded and exchanged for $100 \mu \mathrm{l} 50 \mathrm{mM}$ $\mathrm{ABC} / 50 \% \mathrm{ACN}$ with $50 \mathrm{mM}$ DTT and sonicated for $5 \mathrm{~min}$ utes to remove any excess iodoacetamide. The supernatant was discarded and samples were sonicated for 5 minutes in $100 \mu \mathrm{l}$ of HPLC water. The water was discarded and samples were sonicated for another 5 minutes in $100 \mu$ lof ACN. ACN was discarded and microtubes with samples were left open for a couple of minutes to allow the rest of ACN to evaporate. Five ng of trypsin (Promega) in $10 \mu \mathrm{l}$ of $50 \mathrm{mM} \mathrm{ABC}$ were added to the gel. Samples were incubated at $37^{\circ} \mathrm{C}$ overnight. Trifluoroacetic acid (TFA) and ACN were added to reach final concentration 1\% TFA, $30 \%$ ACN. Samples were sonicated for 10 minutes and 0.5 $\mu \mathrm{l}$ drop was transferred onto MALDI target and let to dry. Dried droplets were covered with $0.5 \mu \mathrm{l}$ drop of alphacyano-hydroxycinnamic acid solution $(2 \mathrm{mg} / \mathrm{ml}$ in $80 \%$ ACN) and let to dry. Samples were measured using a 4800 Plus MALDI TOF/TOF analyzer (Applied Biosystems/ MDS Sciex) equipped with a Nd:YAG laser (355 nm, firing rate $200 \mathrm{~Hz}$ ).

Peak lists from the MS spectra were generated by 4000 Series Explorer V 3.5.3 (Applied Biosystems/MDS Sciex) without smoothing, peaks with local signal to noise ratio greater than 5 were picked and searched by local Mascot $\mathrm{v}$. 2.1 (Matrix Science) against a database of proteins sequences derived from cDNA library. Database search criteria were as follows - enzyme: trypsin, taxonomy: none, fixed modification: carbamidomethylation, variable modification: methionine oxidation, peptide mass 
tolerance: $120 \mathrm{ppm}$, one missed cleavage allowed. Only hits that were scored as significant $(\mathrm{p}<0.0001)$ are included.

For the Edman degradation analysis, Phlebotomus arabicus salivary glands were electrophoretically separated on 1 mm thick 4-20\% NuPAGE Novex Bis-Tris gels using MES SDS buffer (Invitrogen). A sample containing 30 glands was reduced with NuPAGE Sample Reducing Agent (Invitrogen) and run in parallel with non-reduced samples (50 glands) on the same gel. Wet blotting on a PVDF membrane was performed using XCell $\mathrm{II}^{\mathrm{TM}}$ Blot Module (Invitrogen). SeeBlue ${ }^{\circledast}$ Pre-Stained Standards (Invitrogen) were used to estimate molecular weight $\left(\mathrm{M}_{\mathrm{w}}\right)$ of separated proteins and assess transfer efficiency. The membrane was stained with $0.025 \%$ Coomassie blue without acetic acid. Stained bands were cut and subjected to Edman degradation using a Procise 494cLC sequencer (Applied Biosystems). cDNA sequences corresponding to obtained $\mathrm{N}$ terminal amino acid sequences of salivary proteins were identified using an in-house search program [29]. This program compared three possible translations of each cDNA sequence obtained in the $P$. arabicus cDNA sequencing project with the amino acid sequences.

\section{Enzymatic assays}

Salivary gland samples from 5-day-old $P$. arabicus females were tested for the activities of hyaluronidase and phospholipase A2. Salivary glands were dissected in Tris buffer ( $20 \mathrm{mM}$ Tris, $150 \mathrm{mM} \mathrm{NaCl}, \mathrm{pH} 7.8$ ) and stored at $-20^{\circ} \mathrm{C}$. Before use, the glands were mechanically disrupted, samples were centrifuged at $12000 \mathrm{~g}$ for 5 minutes, and the supernatant was used in the assays.

The zymographic hyaluronidase assay was performed as described by Volfova et al. [35]. Briefly, salivary gland samples were separated by SDS electrophoresis in $8 \%$ polyacrylamide slab gels with incorporated hyaluronan $(0.002 \%)$. Prior to electrophoresis, aliquots of the sample were subjected to treatment with reducing agents (dithiothreitol $50 \mathrm{mM}, 45$ minutes at $25^{\circ} \mathrm{C}$, or 2-mercaptoethanol $7 \mathrm{mM}, 45$ minutes at $40^{\circ} \mathrm{C}$ ). An equivalent of 1 salivary gland per lane was used for electrophoresis under reducing conditions using dithiothreitol, an equivalent of 2 salivary glands per lane for electrophoresis under reducing conditions using 2-mercaptoethanol, and for electrophoresis under non-reducing conditions, an equivalent of $1 / 12$ of a gland per lane was used. After the electrophoresis, SDS was washed out of the gels; the gels were equilibrated with $0.1 \mathrm{M}$ acetate buffer and incubated at $37^{\circ} \mathrm{C}$ for 120 minutes. Gels stained with Stains-all (Sigma) were rinsed in distilled water and documented.

The phospholipase A2 activity was tested in the same salivary gland samples using the EnzChek ${ }^{\circledast}$ Phospholipase $\mathrm{A}_{2}$
Assay Kit (Invitrogen). The manufacturer's instructions were followed. Samples containing 0.5, 1, 2, 5, 10 and 20 salivary glands in $50 \mu \mathrm{l}$ were assayed; as a positive control, PLA2 from honey bee venom supplied with the kit was used. The assay was performed at $26^{\circ} \mathrm{C}$, and fluorescence emission at $515 \mathrm{~nm}$ was detected after an incubation step of 12 minutes (Tecan Infinite 200).

\section{Immunization of mice}

Experiments on mice were done in accordance with Czech Act No. 246/1992 and approved by IACUC of the Faculty of Science, Charles University in Prague. Female BALB/c mice, 8 weeks old (Charles River Deutschland, Sulzfeld, Germany) were used for the exposure to $P$. arabicus sand flies. In biweekly intervals, the mice were anaesthetized with ketamine $(1.5 \mathrm{mg} / 10 \mathrm{~g}$ body weight) and xylazin $(0.15 \mathrm{mg} / 10 \mathrm{~g}$ body weight) and exposed to sand fly females. Each time, an average of 60 females fed on each mouse $(\mathrm{SE}=14.9)$. Ten days after the sixth exposure the mice were bled and obtained sera were kept at $-20^{\circ} \mathrm{C}$.

\section{Western blotting}

Phlebotomus arabicus salivary gland proteins were disrupted by three freeze-thaw cycles in liquid nitrogen and separated by SDS-PAGE on $12 \%$ polyacrylamide gel, 0.75 $\mathrm{mm}$ thick using Mini-Protean III apparatus (BioRad). As a reducing agent, $2.5 \%$ 2-mercaptoethanol was used in sample buffer. Biotinylated low range standards (BioRad) were run on the same gel. Separated proteins were electrotransferred onto a nitrocellulose membrane by iBlot $^{\mathrm{TM}} \mathrm{Gel}$ Transfer Device (Invitrogen), and the membrane was cut into strips corresponding to sample load of 5 salivary glands per strip. These strips carrying salivary gland samples were either stained with amidoblack (Merck; 0.1\% solution in $25 \%$ isopropanol and $10 \%$ acetic acid) or blocked with $5 \%$ BSA in phosphate-buffered saline, $\mathrm{pH}$ 7.4 , with $0.05 \%$ Tween-20 (PBS-Tw) overnight. The sample-carrying strips were incubated for 1 hour with preimmune or immune sera of BALB/C mice exposed to $P$. arabicus (diluted 1:250 in PBS-Tw), and then with horseradish peroxidase-conjugated swine anti-mouse antibody (Sevapharma, 1:1000 in PBS-Tw) for 45 minutes. Streptavidin-conjugated peroxidase (Sigma, $1 \mu \mathrm{g} / \mathrm{ml}$ in PBS-Tw) was used for the biotinylated standards. The colour reaction was developed using $\mathrm{H}_{2} \mathrm{O}_{2}$ and diaminobenzidine in PBS. Washes between individual steps were done with PBS-Tw.

\section{Authors' contributions}

$\mathrm{JH}$ participated in the cDNA library construction and annotation, sequence alignment and phylogenetic analysis, immunization of mice by sand flies and the detection of humoral response to sand fly saliva, and drafting the manuscript. JM sequenced all cDNA clones selected from the library. VV dissected the salivary glands and carried 
out the enzymatic assays. IR participated in sample preparation for Edman degradation, which was carried out by MG. PV and JGV conceived the study, participated in its design and coordination and revised the manuscript. RCJ carried out the bioinformatic analysis of transcript sequences, participated in coordination of the study and drafting the manuscript. All authors have read and approved the final manuscript.

\section{Acknowledgements}

We thank Petr Jedelsky for help with the mass spectrometry analysis, Dr. Helena Kulíková and Dušan Eremiáš for helpful technical and administrative assistance. Participation of Iva Rohoušová was supported by the Fulbright Scholar Program. The study was partially supported by projects MSM 0021620828, LC 06009, and The Division of Intramural Research, The National Institute of Allergy and Infectious Diseases.

\section{References}

I. Ribeiro JM: Role of saliva in blood-feeding by arthropods. Annu Rev Entomol 1987, 32:463-478.

2. Rohousova I, Volf P: Sand fly saliva: effects on host immune response and Leishmania transmission. Folia Parasitol (Praha) 2006, 53(3): $|6|-|7|$.

3. Gebre-Michael T, Balkew M, Ali A, Ludovisi A, Gramiccia M: The isolation of Leishmania tropica and $L$. aethiopica from Phlebotomus (Paraphlebotomus) species (Diptera: Psychodidae) in the Awash Valley, northeastern Ethiopia. Trans $R$ Soc Trop Med Hyg 2004, 98(I):64-70.

4. Jacobson RL, Eisenberger CL, Svobodova M, Baneth G, Sztern J, Carvalho J, Nasereddin A, El Fari M, Shalom U, Volf P, et al.: Outbreak of cutaneous leishmaniasis in northern Israel. J Infect Dis 2003, | 88(7): 1065-1073.

5. Svobodova M, Votypka J, Peckova J, Dvorak V, Nasereddin A, Baneth G, Sztern J, Kravchenko V, Orr A, Meir D, et al.: Distinct transmission cycles of Leishmania tropica in $\mathbf{2}$ adjacent foci, Northern Israel. Emerg Infect Dis 2006, I 2(1 2): I 860-1868.

6. Jacobson RL: Leishmania tropica (Kinetoplastida: Trypanosomatidae) - a perplexing parasite. Folia Parasitol (Praha) 2003, 50(4):24I-250.

7. Myskova J, Svobodova M, Beverley SM, Volf P: A lipophosphoglycan-independent development of Leishmania in permissive sand flies. Microbes Infect 2007, 9(3):317-324.

8. Aransay AM, Scoulica E, Tselentis Y, Ready PD: Phylogenetic relationships of phlebotomine sandflies inferred from small subunit nuclear ribosomal DNA. Insect Mol Biol 2000, 9(2): I57-I68.

9. Elnaiem DE, Meneses C, Slotman M, Lanzaro GC: Genetic variation in the sand fly salivary protein, SP-15, a potential vaccine candidate against Leishmania major. Insect Mol Biol 2005, I4(2): I $45-150$.

10. Anderson JM, Oliveira F, Kamhawi S, Mans BJ, Reynoso D, Seitz AE, Lawyer P, Garfield M, Pham M, Valenzuela JG: Comparative salivary gland transcriptomics of sandfly vectors of visceral leishmaniasis. BMC Genomics 2006, 7:52.

II. Valenzuela JG, Belkaid Y, Garfield MK, Mendez S, Kamhawi S, Rowton ED, Sacks DL, Ribeiro JM: Toward a defined anti-Leishmania vaccine targeting vector antigens: characterization of a protective salivary protein. J Exp Med 200I, I 94(3):33I-342.

12. Andersen JF, Pham VM, Meng Z, Champagne DE, Ribeiro JM: Insight into the Sialome of the Black Fly, Simulium vittatum. J Proteome Res 2009, 8(3): I 474-| 488.

13. Campbell CL, Vandyke KA, Letchworth GJ, Drolet BS, Hanekamp T, Wilson WC: Midgut and salivary gland transcriptomes of the arbovirus vector Culicoides sonorensis (Diptera: Ceratopogonidae). Insect Mol Biol 2005, I 4(2): $121-136$.

14. James AA, Blackmer K, Marinotti O, Ghosn CR, Racioppi JV: Isolation and characterization of the gene expressing the major salivary gland protein of the female mosquito, Aedes aegypti. Mol Biochem Parasitol 199I, 44(2):245-253.

15. Valenzuela JG, Charlab R, Gonzalez EC, de Miranda-Santos IK, Marinotti O, Francischetti IM, Ribeiro JM: The D7 family of salivary proteins in blood sucking diptera. Insect Mol Biol 2002, II(2): I 49-I 55

16. Calvo E, Mans BJ, Andersen JF, Ribeiro JM: Function and evolution of a mosquito salivary protein family. J Biol Chem 2006, 28 I (4): 1935-1942.

17. Isawa $\mathrm{H}$, Orito $\mathrm{Y}$, Iwanaga $S$, Jingushi $N$, Morita $A$, Chinzei $Y$, Yuda $M$ : Identification and characterization of a new kallikrein-kinin system inhibitor from the salivary glands of the malaria vector mosquito Anopheles stephensi. Insect Biochem Mol Biol 2007, 37(5):466-477

18. Mans BJ, Calvo E, Ribeiro JM, Andersen JF: The crystal structure of D7r4, a salivary biogenic amine-binding protein from the malaria mosquito Anopheles gambiae. J Biol Chem 2007, 282(50):36626-36633.

19. Peng Z, Li H, Simons FE: Immunoblot analysis of salivary allergens in 10 mosquito species with worldwide distribution and the human IgE responses to these allergens. J Allergy Clin Immunol I998, IOI (4 Pt I):498-505.

20. Bahia D, Gontijo NF, Leon IR, Perales J, Pereira MH, Oliveira G, Correa-Oliveira $R$, Reis $A B$ : Antibodies from dogs with canine visceral leishmaniasis recognise two proteins from the saliva of Lutzomyia longipalpis. Parasitol Res 2007, 100(3):449-454.

2I. Johnson JK, Li J, Christensen BM: Cloning and characterization of a dopachrome conversion enzyme from the yellow fever mosquito, Aedes aegypti. Insect Biochem Mol Biol 200I, 3 I (I I): I I25-I I 35.

22. Li J, Zhao X, Christensen BM: Dopachrome conversion activity in Aedes aegypti: significance during melanotic encapsulation of parasites and cuticular tanning. Insect Biochem Mol Biol 1994, 24(10): 1043-1049.

23. Volf $P$, Skarupova $S$, Man $P$ : Characterization of the lectin from females of Phlebotomus duboscqi sand flies. Eur J Biochem 2002, 269(24):6294-630।

24. Gomes RB, Brodskyn C, de Oliveira Cl, Costa J, Miranda JC, Caldas A, Valenzuela JG, Barral-Netto M, Barral A: Seroconversion against Lutzomyia longipalpis saliva concurrent with the development of anti-Leishmania chagasi delayed-type hypersensitivity. J Infect Dis 2002, 186(10): 1530-1534.

25. Hostomska J, Rohousova I, Volfova V, Stanneck D, Mencke N, Volf P: Kinetics of canine antibody response to saliva of the sand fly Lutzomyia longipalpis. Vector Borne Zoonotic Dis 2008, 8(4):443-450.

26. Rohousova I, Ozensoy S, Ozbel Y, Volf P: Detection of speciesspecific antibody response of humans and mice bitten by sand flies. Parasitology 2005, I 30(Pt 5):493-499.

27. Fang KS, Vitale M, Fehlner P, King TP: cDNA cloning and primary structure of a white-face hornet venom allergen, antigen 5 . Proc Natl Acad Sci USA 1988, 85(3):895-899.

28. Charlab R, Valenzuela JG, Rowton ED, Ribeiro JM: Toward an understanding of the biochemical and pharmacological complexity of the saliva of a hematophagous sand fly Lutzomyia longipalpis. Proc Natl Acad Sci USA 1999, 96(26): 15I55-15160.

29. Valenzuela JG, Pham VM, Garfield MK, Francischetti IM, Ribeiro JM: Toward a description of the sialome of the adult female mosquito Aedes aegypti. Insect Biochem Mol Biol 2002, 32(9): I I0I-II 22

30. Oliveira F, Kamhawi S, Seitz AE, Pham VM, Guigal PM, Fischer L, Ward J, Valenzuela JG: From transcriptome to immunome: identification of DTH inducing proteins from a Phlebotomus ariasi salivary gland cDNA library. Vaccine 2006, 24(3):374-390.

31. Champagne DE: Antihemostatic molecules from saliva of blood-feeding arthropods. Pathophysiol Haemost Thromb 2005, 34(4-5):22I-227.

32. Valenzuela JG, Belkaid $Y$, Rowton E, Ribeiro JM: The salivary apyrase of the blood-sucking sand fly Phlebotomus papatasi belongs to the novel Cimex family of apyrases. J Exp Biol 200I, 204:229-237.

33. Sansom FM, Robson SC, Hartland EL: Possible effects of microbial ecto-nucleoside triphosphate diphosphohydrolases on hostpathogen interactions. Microbiol Mol Biol Rev 2008, 72(4):765-78I.

34. Cerna $P$, Mikes $L$, Volf $P$ : Salivary gland hyaluronidase in various species of phlebotomine sand flies (Diptera: psychodidae). Insect Biochem Mol Biol 2002, 32(1 2): 169|-1697. 
35. Volfova V, Hostomska J, Cerny M, Votypka J, Volf P: Hyaluronidase of bloodsucking insects and its enhancing effect on leishmania infection in mice. PLoS Negl Trop Dis 2008, 2(9):e294.

36. Jacobson RL, Schlein Y: Phlebotomus papatasi and Leishmania major parasites express alpha-amylase and alpha-glucosidase. Acta Trop 200I, 78( I):4I-49.

37. Kato H, Anderson JM, Kamhawi S, Oliveira F, Lawyer PG, Pham VM, Sangare CS, Samake S, Sissoko I, Garfield M, et al.: High degree of conservancy among secreted salivary gland proteins from two geographically distant Phlebotomus duboscqi sandflies populations (Mali and Kenya). BMC Genomics 2006, 7:226.

38. Deissler H, Lottspeich F, Rajewsky MF: Affinity purification and cDNA cloning of rat neural differentiation and tumor cell surface antigen gp I 30RB I 3-6 reveals relationship to human and murine PC-I. J Biol Chem I995, 270(I 7):9849-9855.

39. Jochim RC, Teixeira CR, Laughinghouse A, Mu J, Oliveira F, Gomes $R B$, Elnaiem DE, Valenzuela JG: The midgut transcriptome of Lutzomyia longipalpis: comparative analysis of cDNA libraries from sugar-fed, blood-fed, post-digested and Leishmania infantum chagasi-infected sand flies. BMC Genomics 2008, 9:I5.

40. Ramalho-Ortigao M, Jochim RC, Anderson JM, Lawyer PG, Pham VM, Kamhawi S, Valenzuela JG: Exploring the midgut transcriptome of Phlebotomus papatasi: comparative analysis of expression profiles of sugar-fed, blood-fed and Leishmania-majorinfected sandflies. BMC Genomics 2007, 8:300.

4I. Clements AN: The biology of mosquitoes. development, nutrition and reproduction. Volume $I$. Ist edition. Chapman \& Hall; London; 1992

42. Peiren N, de Graaf DC, Brunain M, Bridts CH, Ebo DG, Stevens WJ, Jacobs FJ: Molecular cloning and expression of icarapin, a novel IgE-binding bee venom protein. FEBS Lett 2006 580(20):4895-4899.

43. Volf $\mathrm{P}$, Tesarova $\mathrm{P}$, Nohynkova EN: Salivary proteins and glycoproteins in phlebotomine sandflies of various species, sex and age. Med Vet Entomol 2000, I4(3):25I-256.

44. Ribeiro JM, Alarcon-Chaidez F, Francischetti IM, Mans BJ, Mather TN, Valenzuela JG, Wikel SK: An annotated catalog of salivary gland transcripts from Ixodes scapularis ticks. Insect Biochem Mol Biol 2006, 36(2): III-129.

45. Benkova I, Volf P: Effect of temperature on metabolism of Phlebotomus papatasi (Diptera: Psychodidae). J Med Entomol 2007, 44(I): I50-I54.

46. Chmelar J, Anderson JM, Mu J, Jochim RC, Valenzuela JG, Kopecky J: Insight into the sialome of the castor bean tick, Ixodes ricinus. BMC Genomics 2008, 9:233.

47. Ewing B, Green P: Base-calling of automated sequencer traces using phred. II. Error probabilities. Genome Res 1998 8(3): $186-194$

48. Ewing B, Hillier L, WendI MC, Green P: Base-calling of automated sequencer traces using phred. I. Accuracy assessment. Genome Res 1998, 8(3): I75-185.

49. Huang $X$, Madan A: CAP3: A DNA sequence assembly program. Genome Res 1999, 9(9):868-877.

50. Altschul SF, Madden TL, Schaffer AA, Zhang J, Zhang Z, Miller W, Lipman DJ: Gapped BLAST and PSI-BLAST: a new generation of protein database search programs. Nucleic Acids Res 1997, 25(1 7):3389-3402.

51. Ashburner M, Ball CA, Blake JA, Botstein D, Butler H, Cherry JM, Davis AP, Dolinski K, Dwight SS, Eppig JT, et al.: Gene ontology: tool for the unification of biology. The Gene Ontology Consortium. Nat Genet 2000, 25(I):25-29.

52. Marchler-Bauer A, Panchenko AR, Shoemaker BA, Thiessen PA, Geer LY, Bryant SH: CDD: a database of conserved domain alignments with links to domain three-dimensional structure. Nucleic Acids Res 2002, 30(I):28I-283.

53. Tatusov RL, Fedorova ND, Jackson JD, Jacobs AR, Kiryutin B, Koonin EV, Krylov DM, Mazumder R, Mekhedov SL, Nikolskaya AN, et al.: The COG database: an updated version includes eukaryotes. BMC Bioinformatics 2003, 4:4I

54. Bateman A, Birney E, Durbin R, Eddy SR, Howe KL, Sonnhammer EL: The Pfam protein families database. Nucleic Acids Res 2000, 28(I):263-266.

55. Schultz J, Copley RR, Doerks T, Ponting CP, Bork P: SMART: a web-based tool for the study of genetically mobile domains. Nucleic Acids Res 2000, 28(I):231-234.
56. Bendtsen JD, Nielsen H, von Heijne G, Brunak S: Improved prediction of signal peptides: SignalP 3.0. J Mol Biol 2004, 340(4):783-795.

57. Julenius K, Molgaard A, Gupta R, Brunak S: Prediction, conservation analysis, and structural characterization of mammalian mucin-type O-glycosylation sites. Glycobiology 2005, I5(2): I53-164.

58. Higgins DG, Sharp PM: CLUSTAL: a package for performing multiple sequence alignment on a microcomputer. Gene 1988, 73(I):237-244

59. Abascal F, Zardoya R, Posada D: ProtTest: selection of best-fit models of protein evolution. Bioinformatics 2005, 2 I(9):2 $104-2105$

60. Schmidt HA, Strimmer K, Vingron M, von Haeseler A: TREE-PUZZLE: maximum likelihood phylogenetic analysis using quartets and parallel computing. Bioinformatics 2002, I 8(3):502-504.

61. Tamura K, Dudley J, Nei M, Kumar S: MEGA4: Molecular Evolutionary Genetics Analysis (MEGA) software version 4.0. Mol Biol Evol 2007, 24(8): I596-1599.
Publish with BioMed Central and every scientist can read your work free of charge

"BioMed Central will be the most significant development for disseminating the results of biomedical research in our lifetime. "

Sir Paul Nurse, Cancer Research UK

Your research papers will be:

- available free of charge to the entire biomedical community

- peer reviewed and published immediately upon acceptance

- cited in PubMed and archived on PubMed Central

- yours - you keep the copyright
BioMedcentral 